\title{
Diversity of Staphylococcus species and prevalence of enterotoxin genes isolated from milk of healthy cows and cows with subclinical mastitis
}

\author{
V. L. M. Rall, ${ }^{* 1}$ E. S. Miranda, ${ }^{*}$ I. G. Castilho, ${ }^{*}$ C. H. Camargo, ${ }^{*}$ H. Langoni,† F. F. Guimarães, $\dagger$ \\ J. P. Araújo Júnior, ${ }^{*}$ and A. Fernandes Júnior* \\ *Department of Microbiology and Immunology, and \\ †Department of Hygiene Veterinary and Public Health, Universidade Estadual Paulista (UNESP), Botucatu, SP 18618-380, Brazil
}

\begin{abstract}
The objectives of this study were to determine the occurrence and diversity of Staphylococcus spp. in milk from healthy cows and cows with subclinical mastitis in Brazil and to examine the profile of enterotoxin genes and some enterotoxins produced by Staphylococcus spp. A total of 280 individual mammary quarter milk samples from 70 healthy cows and 292 samples from 73 cows with subclinical mastitis were collected from 11 farms in the state of São Paulo, Brazil. Staphylococcus spp. were recovered from $63(22.5 \%)$ samples from healthy cows and from 80 samples $(27.4 \%)$ from cows with mastitis. The presence of Staphylococcus aureus was significantly different between these 2 groups and was more prevalent in the cows with mastitis. The presence of Staphylococcus saprophyticus was also significantly different between these 2 groups, but this organism was more prevalent in healthy cows. No statistically significant differences were observed in the numbers of other staphylococci in milk samples from the 2 groups. The sea gene was the most prevalent enterotoxin gene in both groups. Eight of 15 (53.3\%) Staph. aureus carried this gene and all produced the SEA toxin. In the coagulase-negative staphylococci (CNS) group, 61 of $128(47.5 \%)$ had the same gene and just $1(1.6 \%)$ Staphylococcus epidermidis strain produced the enterotoxin in vitro. Because CNS were isolated from both groups of cows and most CNS contained enterotoxin genes but did not produce toxins, the role of CNS in mastitis should be carefully defined.
\end{abstract}

Key words: Staphylococcus aureus, coagulase-negative staphylococci, mastitis, enterotoxin

\section{INTRODUCTION}

Mastitis is one of the most common infectious diseases in dairy herds (Pol and Ruegg, 2007) and can be classified into clinical and subclinical forms. Clinical

Received July 4, 2013.

Accepted October 19, 2013.

${ }^{1}$ Corresponding author: vlmores@ibb.unesp.br mastitis is defined based on clinical evidence of inflammation in at least one teat or the presence of lumps or flakes in the milk or an abnormal color or consistency of the milk from early jets of milk. In subclinical cases, animals are outwardly healthy and must be diagnosed using the California Mastitis Test (CMT) and SCC (Pantoja et al., 2009).

Staphylococcus are among the microorganisms most commonly isolated in mastitis cases (Pyörälä and Taponen, 2009), and Staphylococcus aureus is the most common cause of bovine mastitis and is responsible for the largest economic losses due to this condition (Melchior et al., 2006). Mastitis caused by this bacterial species may be subclinical or clinical (Pyörälä and Taponen, 2009).

Although Staph. aureus is considered the primary pathogen involved in intramammary infections, the role of CNS in this condition has recently been reexamined. These microorganisms, which were previously thought to be environmental contaminants, are now considered to be a frequent cause of mastitis, particularly subclinical mastitis (Taponen et al., 2007). The CNS seem to increase the number of somatic cells in milk, due to the presence of phagocytes combating local microorganisms, and to decrease milk production, and lead to intraalveolar fibrosis of the breast tissue and loss of secretory function of this tissue (Lüthje and Schwarz, 2006).

Because of the heterogeneity of this genus, which contains 47 species, mastitis caused by CNS is poorly understood and control of CNS mastitis is complicated (DSMZ, 2012). Infection by CNS is a persistent cause of intramammary inflammation, which may persist throughout the months of lactation in the absence of intervention (Gillespie et al., 2009). Park et al. (2011) isolated 263 CNS from milk samples from cows with intramammary infections, identifying 11 species, including Staphylococcus chromogenes (72.2\%), Staphylococcus xylosus (9.1\%), and Staphylococcus haemolyticus (6.1\%), which were the most frequent species isolated.

Staphylococcus aureus produces many extracellular toxins (enterotoxins). These toxins are known to cause 
food poisoning in humans, and they may be involved in other types of infections such as mastitis. Classical staphylococcal enterotoxins (SE) were designated SEA through SEE (Bergdoll and Robbins, 1973). Later, new toxin genes were discovered, including seg, seh, sei, selj, selk, sell, selm, seln, selo, selp, selq, selr, sels, selt, selu, and selv (Betley et al., 1992; Ren et al., 1994; Munson et al., 1998; Jarraud et al., 2001; Kuroda et al., 2001; Orwin et al., 2001, 2003; Letertre et al., 2003; Omoe et al., 2003; Mempel et al., 2003; Thomas et al., 2006; Ono et al., 2008). Some of these enterotoxins are referred to as SE-like toxins, as their emetic properties have not yet been characterized (Lina et al., 2004).

Both coagulase-negative and coagulase-positive staphylococci carry genes for the production of these enterotoxins (Rall et al., 2010; Aydin et al., 2011; Park et al., 2011). However, although Staph. aureus is a strong enterotoxin producer, CNS seem to produce these enterotoxins at a low level, even under optimal conditions, or to not produce these toxins at all (Robbins et al., 1974; Rall et al., 2010; Aydin et al., 2011). Thus, this study aimed to examine the distribution of Staphylococcus species in milk samples from healthy cows and cows with subclinical mastitis and to determine the presence of genes for enterotoxins.

\section{MATERIALS AND METHODS}

\section{Milk Samples}

A total of 280 milk samples from 70 healthy cows (from the 4 mammary glands) and 292 milk samples from 73 cows with subclinical mastitis were collected over 12 mo from 10 farms in the state of São Paulo, Brazil. The samples were collected in sterile tubes after disinfection of the ostium with iodized alcohol (2.5\%), and they were transported to the laboratory under refrigeration $\left(4-8^{\circ} \mathrm{C}\right)$ in cool boxes with ice packs. All of the handlers used sterilized latex gloves.

The interpretation criteria used for diagnosis of subclinical mastitis were based on the CMT (Schalm and Noorlander, 1957) and SCC. Briefly, in the CMT, after excluding the first streams of milk, $3 \mathrm{~mL}$ of each milk sample was collected from a specific tray of the kit and an equivalent volume of the test reagent was added; the test reagent contained $10 \mathrm{mg}$ of bromocresol purple, $1.5 \mathrm{~g}$ of sodium hydroxide, $15 \mathrm{~mL}$ of Teepol broth, and $1,000 \mathrm{~mL}$ of distilled water. The samples were scored from a range of negative to 5 plus signs (strongly positive), and samples with a score of at least 2 were suspected to be from cows with IMI and were subjected to somatic cell counting to confirm infection. This analysis was performed by flow cytometry using a Somacount
300 instrument (Bentley Instruments, Chaska, MN). Animals whose milk samples had $>200,000$ cells $/ \mathrm{mL}$ and a positive CMT score of at least 2 and no clinical evidence of infection were classified as having subclinical mastitis (Pantoja et al., 2009).

\section{Isolation and Identification of Staphylococcus spp.}

All tests were performed with culture media from Oxoid (Basingstoke, UK) unless otherwise specified. The isolation of staphylococci was performed on BairdParker agar incubated at $35^{\circ} \mathrm{C}$ for $48 \mathrm{~h}$. Characteristic colonies (black, with or without a halo) were tested for catalase, coagulase, and thermostable nuclease (TNase). Coagulase-positive species were subjected to testing with the Staphytect Dry Spot Test Kit (Oxoid). To separate the coagulase-positive species, we performed the Voges-Proskauer and $\beta$-galactosidase tests. A PCR for the coa and nuc genes was also performed using the protocol of Cremonesi et al. (2005).

The CNS strains were submitted to an antibiogram with bacitracin $(0.04 \mathrm{U})$ and furazolidone $(100 \mu \mathrm{g})$ to separate them from members of the genus Kocuria. Finally, the strains were identified using API Staph (BioMérieux, Marcy l'Etoile, France) and molecular methods, with sodA degenerate primers and the sequences were submitted to the European Molecular Biology Laboratory (EMBL) gene bank (Poyart et al., 2001).

\section{PCR Testing for Genes Encoding Staphylococcal Enterotoxins}

The Minispin Kit (GE Healthcare, Little Chalfont, UK) was used for DNA isolation according to the manufacturer's instructions. The primers used for the detection of SE genes are listed in Table 1. As positive controls, PCR reactions containing template DNA extracted from the standard Staph. aureus strains ATCC 13565 (sea), ATCC 14458 (seb), ATCC 19095 (sec), FRI 361 (sed, seg, sei and sej, sel, sem, sen, seo, ser), ATCC 27664 (see), FRI 137 (seh), FRI 326 (seq), and FRI 913 (sek) were carried out in parallel. Some additional PCR reactions received ultrapure water instead of template DNA to provide negative controls. One sample of each of sea, seb, sec, sed, see, seg, seh, sei, sej, sell, selm, seln, selo, selp, and selr amplicons was sequenced and the partial sequences were confirmed to correspond to GenBank accession numbers M18970, M11118, X05815, M28521, M21319, AY920261, U11702, AY920268, AB075606, AB679717.1, HE579071.1, HE579069.1, HE579073.1, FR714927.1, and GQ900416.1, respectively. 
Table 1. Primers and their characteristics used for the detection of Staphylococcus spp. staphylococcal enteroxin genes

\begin{tabular}{|c|c|c|c|c|}
\hline Gene & Sequence $\left(5^{\prime}-3^{\prime}\right)$ & $\begin{array}{l}\text { Product } \\
\text { size, bp }\end{array}$ & $\begin{array}{c}\text { Annealing } \\
\text { temperature, }{ }^{\circ} \mathrm{C}\end{array}$ & Reference \\
\hline sea 1 & TTGGAAACGGTTAAAACGAA & & & \\
\hline sea 2 & GAACCTTCCCATCAAAAACA & 120 & 50 & Johnson et al. (1991) \\
\hline seb 1 & TCGCATCAAACTGACAAACG & & & \\
\hline seb 2 & GCAGGTACTCTATAAGTGCC & 478 & 50 & Johnson et al. (1991) \\
\hline $\sec 1$ & GACATAAAAGCTAGGAATTT & & & \\
\hline sec 2 & AAATCGGATTAACATTATCC & 257 & 50 & Johnson et al. (1991) \\
\hline sed 1 & CTAGTTTGGTAATATCTCCT & & & \\
\hline sed 2 & TAATGCTATATCTTATAGGG & 317 & 50 & Johnson et al. (1991) \\
\hline see 1 & AGGTTTTTTCACAGGTCATCC & & & \\
\hline see 2 & CTTTTTTTTCTTCGGTCAATC & 209 & 50 & Mehrotra et al. (2000) \\
\hline $\operatorname{seg} 1$ & AAGTAGACATTTTTGGCGTTCC & & & \\
\hline $\operatorname{seg} 2$ & AGAACCATCAAACTCGTATAGC & 287 & 55 & Omoe et al. (2002) \\
\hline $\operatorname{seh} 1$ & GTCTATATGGAGGTACAACACT & & & \\
\hline seh 2 & GACCTTTACTTATTTCGCTGTC & 213 & 46.4 & Omoe et al. (2002) \\
\hline sei 1 & GGTGATATTGGTGTAGGTAAC & & & \\
\hline sei 2 & ATCCATATTCTTTGCCTTTACCAG & 454 & 50 & Omoe et al. (2002) \\
\hline $\operatorname{selj} 1$ & CATCAGAACTGTTGTTCCGCTAG & & & \\
\hline selj 2 & CTGAATTTTACCATCAAAGGTAC & 142 & 50 & Nashev et al. (2004) \\
\hline selk 1 & TAGGTGTCTCTAATAATGCCA & & & \\
\hline selk 2 & TAGATATTCGTTAGTAGCTG & 293 & 55 & Omoe et al. (2005) \\
\hline sell 1 & TAACGGCGATGTAGGTCCAGG & & & \\
\hline sell 2 & CATCTATTTCTTGTGCGGTAAC & 383 & 55 & Omoe et al. (2005) \\
\hline selm 1 & GGATAATTCGACAGTAACAG & & & \\
\hline selm 2 & TCCTGCATTAAATCCAGAAC & 379 & 55 & Omoe et al. (2005) \\
\hline $\operatorname{seln} 1$ & TATGTTAATGCTGAAGTAGAC & & & \\
\hline $\operatorname{seln} 2$ & ATTTCCAAAATACAGTCCATA & 282 & 55 & Omoe et al. (2005) \\
\hline selo 1 & TGTGTAAGAAGTCAAGTGTAG & & & \\
\hline selo 2 & TCTTTAGAAATCGCTGATGA & 214 & 55 & Omoe et al. (2005) \\
\hline $\operatorname{selp} 1$ & TGATTTATTAGTAGACCTTGG & & & \\
\hline $\operatorname{selp} 2$ & ATAACCAACCGAATCACCAG & 396 & 55 & Omoe et al. (2005) \\
\hline selq 1 & AATCTCTGGGTCAATGGTAAGC & & & \\
\hline selq 2 & TTGTATTCGTTTTGTAGGTATTTTCG & 122 & 55 & Omoe et al. (2005) \\
\hline selr 1 & GGATAAAGCGGTAATAGCAG & & & \\
\hline selr 2 & GTATTCCAAACACATCTAAC & 166 & 55 & Omoe et al. (2005) \\
\hline nuс 1 & AGTTCAGCAAATGCATCACA & & & \\
\hline nuc 2 & TAGCCAAGCCTTGACGAACT & 400 & 55 & Cremonesi et al. (2005) \\
\hline coa 1 & CCGCTTCAACTTCAGCCTAC & & & \\
\hline coa 2 & TTAGGTGCTACAGGGGCAAT & 204 & 57 & Cremonesi et al. (2005) \\
\hline RNAr 1 & CCTATAAGACTGGGATAACTTCGGG & & & \\
\hline$R N A r 2$ & CTTTGAGTTTCAACCTTGCGGTCG & 791 & 57 & Mason et al. (2001) \\
\hline
\end{tabular}

\section{Classical Enterotoxin Production by Staphylococcus spp.}

The Staph. aureus strains were cultivated in brainheart infusion (BHI) broth and incubated overnight at $37^{\circ} \mathrm{C}$. A volume of $0.1 \mathrm{~mL}$ was spread on sterilized cellophane over BHI agar with $1 \%$ yeast extract, and the Petri dishes were incubated overnight at $37^{\circ} \mathrm{C}$. After this period, $2.5 \mathrm{~mL}$ of $0.01 \mathrm{M} \mathrm{Na}_{2} \mathrm{HPO}_{4}$ was added to the cellophane surface and, after homogenization with the colonies, the volume was transferred to a tube and submitted to centrifugation at $8,900 \times g$ for $10 \mathrm{~min}$ at $4^{\circ} \mathrm{C}$ (Robbins et al., 1974).

For CNS, we used 30- to 40-cm dialysis sacs with 50 $\mathrm{mL}$ of double-concentrated BHI broth. The sacs were placed in 250-mL Erlenmeyer flasks and autoclaved at $121^{\circ} \mathrm{C}$ for 15 min. A loop of CNS (cultured in BHI at $37^{\circ} \mathrm{C}$ overnight) was mixed in $18 \mathrm{~mL}$ of $0.02 \mathrm{M}$ phos- phate buffer in $0.9 \% \mathrm{NaCl}, \mathrm{pH} 7.2$, transferred to the Erlenmeyer flask, and incubated at $37^{\circ} \mathrm{C}$ for $24 \mathrm{~h}$ under agitation $(130 \mathrm{rpm})$. After this period, the cultures were centrifuged at $8,000 \times g$ for $10 \mathrm{~min}$ at $4^{\circ} \mathrm{C}$ (Donnelly et al., 1967).

The supernatants were tested for enterotoxins SEA, SEB, SEC, and SED using the reversed passive latex agglutination assay (RPLA) method (SET-RPLA, Oxoid) according to the manufacturer's instructions. The same positive controls that were used for PCR were also used for the RPLA test.

\section{RESULTS}

We analyzed 280 samples of milk from 70 healthy cows and isolated Staphylococcus spp. from 63 (22.5\%) samples. Of the 292 samples of milk from cows with 
Table 2. Identification of Staphylococcus species isolated from milk of healthy cows or cows with subclinical mastitis

\begin{tabular}{lccr}
\hline Species & $\begin{array}{c}\text { From healthy cows, } \\
\text { no. }(\%)\end{array}$ & $\begin{array}{c}\text { From sick cows, } \\
\text { no. }(\%)\end{array}$ & $\begin{array}{c}\text { Total, } \\
\text { no. }(\%)\end{array}$ \\
\hline Staph. aureus & $1(1.6)$ & $14(17.5)$ & $15(10.5)$ \\
Staph. epidermidis & $11(17.5)$ & $11(13.8)$ & $22(15.4)$ \\
Staph. warneri & $15(23.8)$ & $22(27.5)$ & $37(25.9)$ \\
Staph. haemolyticus & $5(7.9)$ & $7(8.8)$ & $12(8.4)$ \\
Staph. saprophyticus & $19(30.2)$ & $13(16.3)$ & $32(22.4)$ \\
Staph. simulans & $1(1.6)$ & $4(5)$ & $5(3.5)$ \\
Staph. $x y l o s u s$ & $7(11.1)$ & $6(7.5)$ & $13(9.1)$ \\
Staph. cohnii ssp. cohnii & $1(1.6)$ & - & $2(1.4)$ \\
Staph. chromogenes & $2(3.2)$ & $2(2.5)$ & $2(1.4)$ \\
Staph. hominis & $1(1.6)$ & $80(55.9)$ & $1(0.7)$ \\
Staph. capitis & - & & $2(1.4)$ \\
Total & $63(44.1)$ & & $143(100)$ \\
\hline
\end{tabular}

subclinical mastitis, $80(27.4 \%)$ were positive for these Staphylococcus spp.

Table 2 lists the staphylococcal species identified from milk from healthy cows and cows with mastitis. Staphylococcus aureus was the only species that was significantly more prevalent in the milk from cows with mastitis $(P=0.001)$. Staphylococcus saprophyticus was significantly more prevalent in milk from healthy cows $(P=0.02)$. The other staphylococci were present in similar numbers in milk samples from both groups, and no statistically significant differences between groups were seen for these other species.

Staphylococcus saprophyticus was the most frequently isolated CNS in healthy animals $(30.2 \%)$, followed by Staph. warneri (23.8\%) and Staph. epidermidis (17.5\%). In the cows with subclinical mastitis, the most frequently isolated Staphylococcus species was Staph. warneri $(27.5 \%)$, followed by Staph. aureus (17.5\%) and Staph. saprophyticus (16.3\%).

Based on PCR analysis, sea was the most frequently observed enterotoxin gene, occurring in 27 of 63 (42.9\%) isolates of staphylococci isolated from milk of healthy cows and in 42 of $80(52.5 \%)$ isolates from animals with mastitis.

The results of PCR analysis of the presence of genes encoding enterotoxins and the in vitro production of the classical enterotoxins are presented in Table 3. It should be noted that sea was the most frequently detected gene, occurring in $69(48.3 \%)$ of the isolated staphylococci, including samples from both groups of cows, and $9(13 \%)$ of the sea-positive staphylococci produced the SEA enterotoxin.

\section{DISCUSSION}

Members of the genus Staphylococcus are major causative agents of bovine mastitis. In the current study, 292 samples of milk from cows with subclinical mastitis were tested and $27.4 \%$ were positive for these microorganisms.

Staphylococcus aureus is a major pathogen associated with bovine mastitis. This microorganism was detected in $4.8 \%$ of the 292 milk samples from cows with subclinical mastitis that were analyzed in this study. In the United States, Pol and Ruegg (2007) observed Staph. aureus in $2.9 \%$ of samples isolated from cows with subclinical mastitis. In a similar study, Karahan et al. (2009) observed that $28.6 \%$ of such samples were positive for Staph. aureus in Turkey. Out of the 80 strains of staphylococci isolated from cows with subclinical mastitis, Staph. aureus was the second most frequently isolated strain $(17.5 \%)$ in the current study.

We isolated CNS from $66(22.6 \%)$ of the 292 samples of milk from cows with mastitis. Pyörälä and Taponen (2009) concluded that these microorganisms can cause persistent infection, resulting in an increased number of somatic cells in milk, affecting milk quality, and reducing milk production from infected cows. However, our results showed that no CNS species were statistically associated with mastitis cases. In fact, Staph. saprophyticus was significantly $(P=0.02)$ more prevalent in healthy cows. Because CNS are profusely spread on teat apices and other sites of a cow's body as commensal organisms, they can cause mastitis once they are opportunistic pathogens (Taponen et al., 2008; Weese, 2012).

Some staphylococci are normally found on healthy skin of udders or on the hands of milkers. Staphylococcus epidermidis, Staph. simulans, and Staph. warneri are considered to be members of the bacterial microbiota in these regions, whereas Staph. xylosus and Staph. sciuri are considered to be environmental contaminants (Philpot and Nickerson, 2002). Data from this study demonstrate the isolation of several of these species in milk samples from healthy cows or cows with mastitis, with high prevalences of Staph. warneri (25.9\%), Staph. 
Table 3. Presence of enterotoxin genes and production of classical enterotoxins in Staphyloccus spp. isolated from milk of healthy and sick cows

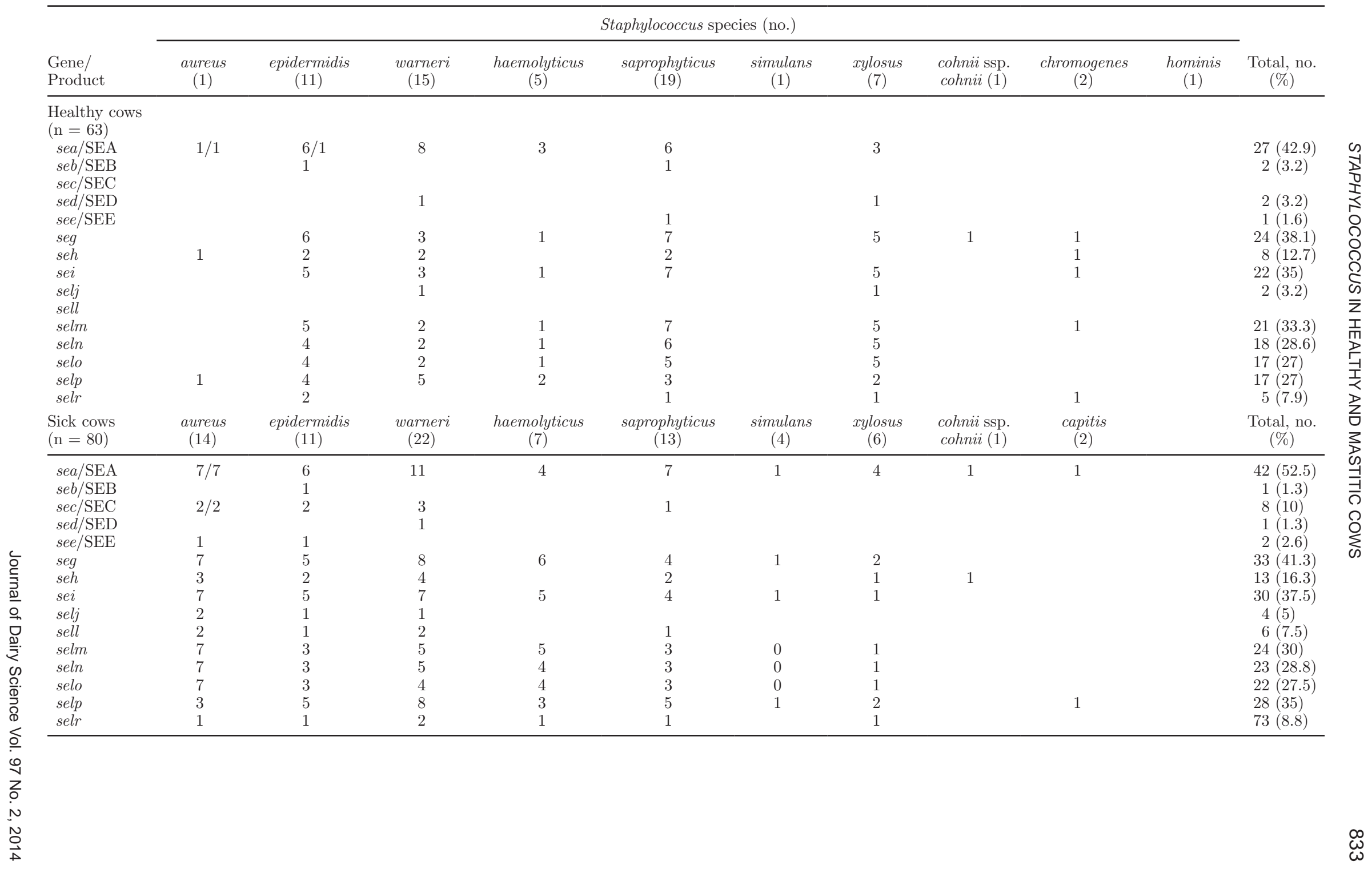


saprophyticus (22.4\%), and Staph. epidermidis (15.4\%) observed.

In the United States, Rajala-Schultz et al. (2004) found that CNS isolates were composed of $65.5 \%$ Staph. chromogenes, $10.1 \%$ Staph. simulans and $4.4 \%$ Staph. epidermidis. Lüthje and Schwarz (2006) isolated a total of 259 CNS strains from subclinical mastitis cases identified in Germany, including Staph. chromogenes (33.2\%), Staph. simulans (23.2\%), Staph. epidermidis $(11.7 \%)$, Staph. xylosus, and Staph. haemolyticus (9.4\%). In a study from Finland, Taponen et al. (2006) isolated CNS samples containing $36.4 \%$ Staph. simulans, $27.3 \%$ Staph. chromogenes, $3 \%$ Staph. haemolyticus, $3 \%$ Staph. warneri, and 5\% Staph. epidermidis, and $1 \%$ Staph. hominis. In another study from the United States, Sawant et al. (2009) found Staph. chromogenes and Staph. epidermidis to be the most prevalent CNS species isolated, and Fessler et al. (2010) found similar results in cows from Germany, where the most frequent species were Staph. chromogenes and Staph. simulans. Park et al. (2011) isolated 263 strains of CNS from IMI of cows in the United States and identified 11 species, including Staph. chromogenes (72.2\%), Staph. xylosus (9.1\%), Staph. haemolyticus (6.1\%), Staph. sciuri ssp. carnaticus (3\%), Staph. hyicus (3\%), Staph. simulans (2.7\%), Staph. caprae (1.1\%), Staph. epidermidis (0.8\%), Staph. succinus (0.8\%), Staph. capitis, and Staph. hominis $(0.4 \%)$.

According to Supré et al. (2011), Staph. chromogenes, Staph. xylosus, Staph. cohnii, and Staph. simulans seem to affect udder health more so than other CNS species. In our study, Staph. chromogenes was not isolated from samples of milk from cows with mastitis and was only found in isolates from healthy cows at a low frequency of $3.2 \%$. Staphylococcus simulans and Staph. cohnii were isolated from samples of milk from cows with mastitis, also at low frequencies (5 and $1.3 \%$, respectively). We isolated Staph. xylosus in 13 of 143 (9.1\%) tested samples, and Ruaro et al. (2013) observed this same value in their study.

From previous papers, the predominant CNS species in milk are Staph. chromogenes and Staph. simulans. All of these studies were conducted in the Northern Hemisphere, where animal handling procedures are very different from those used in Brazil. In previous Brazilian studies (Santos et al., 2010), the authors did not identify CNS at the species level, precluding a discussion of whether they observed increases in the predominant CNS species over what was observed in our study.

Staphylococcus spp. produce many virulence factors, several of which are involved in mastitis, particularly by producing enterotoxins. According to Table 3, sea was the most frequent enterotoxin gene based on our PCR test, occurring in 27 of $63(42.9 \%)$ strains of staphylococci isolated from the milk of healthy cows and in 42 of $80(52.5 \%)$ strains from cows with mastitis. Considering only the Staph. aureus strains, independent of the origin of milk, the frequency of sea isolation increased to $53.3 \%$ (8 of 15). Boynukara et al. (2008) also observed that this gene was the most frequent enterotoxin gene but found sea in only $23.6 \%$ of Staph. aureus strains isolated from subclinical mastitis cases. Findings similar to ours were obtained by Atanassova et al. (2001), who observed that the sea gene was present in $50 \%$ of Staph. aureus strains, and by Morandi et al. (2007), who observed that $48 \%$ of samples were positive for sea. Considering only CNS samples in the current study, the prevalence of sea isolated from healthy animals was $41.3 \%$, whereas the prevalence in cows with mastitis was $43.8 \%$. The phage $\varphi \mathrm{Sa} 3$ encodes the sea $(\varphi \mathrm{Sa} 3 \mathrm{mu})$ and $\operatorname{selp}(\varphi \mathrm{Sa} 3 \mathrm{nu})$ genes, and $\operatorname{selp}$ was observed in 17 of $62(27.4 \%)$ CNS strains isolated from healthy cows in the current study. Considering staphylococci from animals with mastitis, this phage was present in $3(21.4 \%)$ Staph. aureus and 25 (37.9\%) CNS isolates, or a total of 28 isolates (35\%). In both groups of cows, we observed a significant difference considering the presence of these 2 genes $(P=0.002$ for healthy cows and $P<0.001$ for animals with mastitis).

We detected the seb gene in 2 CNS isolates (3.2\%) from milk of healthy cows and 1 isolate (1.5\%) from cows with mastitis; this gene seems to appear at low frequency in Staphylococcus spp. Boynukara et al. (2008) and Wang et al. (2009) found this gene at rates of 1.9 and $2.1 \%$, respectively. In some studies, this gene was not observed (Cremonesi et al., 2005; Morandi et al., 2007; Ruaro et al., 2013).

The gene sec, which encodes SEC, was not found in milk samples from healthy cows but was present in $10 \%$ (8 of 80 ) of the staphylococci strains isolated from cows with mastitis. In an analysis of only Staph. aureus strains, the prevalence of this gene increased to $14.3 \%$; similar frequencies of 15.5 and $16.1 \%$ were observed by Akineden et al. (2001) and Cremonesi et al. (2005), respectively. However, in other studies, this gene was found at low frequency or was not present, including studies by Boynukara et al. (2008) and Karahan et al. (2009).

According to Baba et al. (2002) and Holtfreter and Broker (2005), pathogenicity islands can carry the secsell-tst genes (SaPI2) or only the sec-sell genes (SaPI3). The sell gene was not observed in healthy animals (similar to sec) but was found in $6(7.5 \%)$ strains from cows with mastitis: $2(14.3 \%)$ Staph. aureus strains and $4(6.1 \%)$ CNS strains.

The gene sed appeared at low prevalence and was present in 2 CNS strains (3.2\%) from healthy cows 
and $1(1.5 \%)$ from cows with mastitis. Boynukara et al. (2008) did not detect this gene in 106 Staph. aureus strains isolated from cows with subclinical mastitis.

The genes sed, sellj, and selr are encoded together in plasmid pIB485 (Zhang et al., 1998; Omoe et al., 2003). In the healthy cows in this study, $2(3.2 \%)$ CNS strains contained sed and selj (Staph. warneri and Staph. xylosus). In the cows with mastitis in this study, selj was more frequent than sed. The gene sed occurred in $1(1.3 \%)$ CNS strain (Staph. warneri), and selj was present in 4 (5\%): 2 (14.3\%) Staph. aureus strains and $2(3 \%)$ CNS strains (Staph. warneri and Staph. epidermidis). The gene selr occurred in 5 out of $62(8.1 \%)$ CNS strains isolated from healthy cows and in 7 strains (8.8\%) from cows with mastitis. This gene was present in 1 (7.1\%) Staph. aureus strain and $6(9.1 \%)$ CNS strains. Chiang et al. (2006) found this gene in $5.4 \%$ of 147 Staph. aureus strains in their study.

Only $1(1.6 \%)$ CNS strain from healthy cows was positive for the presence of the see gene, and $2(2.5 \%)$ strains from cows with mastitis were positive for this gene: 1 (7.1\%) Staph. aureus strain and 1 (1.5\%) CNS strain. Morandi et al. (2007), Chiang et al. (2006), and Wang et al. (2009) did not find the see gene in Staph. aureus strains. In an examination of CNS strains, Park et al. (2011) did not observe this gene in 263 strains.

The $s e g$ and sei genes are located together in the egc cluster, which is localized in the type II pathogenicity island vSaß that can also carry the seg-sei-selm-selnselo and, sometimes, selu genes (Wang et al., 2009). In milk samples from healthy animals, seg was observed only in CNS strains and occurred in 24 (38.7\%) strains. In samples from cows with mastitis, the frequency of this gene was higher but not statistically significant $(P$ $=0.73$ ) and the gene was also found in Staph. aureus, occurring in $33(41.3 \%)$ strains: 7 (50\%) Staph. aureus and $26(39.4 \%)$ CNS. This gene was observed at similar frequencies in CNS strains from healthy cows (38.7\%) and cows with mastitis (39.4\%).

We were able to detect the sei gene in 22 of 62 $(35.5 \%)$ CNS strains from healthy animals, and it was found together with seg at a frequency of $91.7 \%$. In samples from cows with mastitis, the sei gene was observed in $30(37.5 \%)$ strains, including $7(50 \%)$ Staph. aureus strains that were positive for seg and $23(34.8 \%)$ additional CNS strains in which the sei gene occurred with seg at a frequency of $88.5 \%$. Despite the lower frequency of sei in relation to seg in both groups of animals, this difference in frequency was not statistically significant $(P=0.52$ and $P=$ 0.26 , respectively). Although these genes are located together in a cluster, this difference can be explained by a mutation in the site of annealing of the primers or a cluster variation in these genes (Jarraud et al.,
2001). Wang et al. (2009) obtained similar results and detected seg and sei in 31.4 and $31.8 \%$ of staphylococci strains, respectively.

The genes selm, seln, and selo were detected at frequencies of $33.8,29$, and $27.4 \%$, respectively, of CNS strains from healthy animals. In samples from cows with mastitis, the rates of detection of these genes were higher: $36.4,34.8$, and $33.3 \%$, but these numbers were not significantly different. Lower frequencies were found by Wang et al. (2009), with $26.9 \%$ positivity for selm, $17.3 \%$ for senl, and selo being absent. In another type of animal product used as food (pork), Hwang et al. (2007) observed that $37 \%$ of samples were positive for both the selm and seln genes and that selo was present in $27 \%$ of the strains.

The gene seh was detected in $8(12.7 \%)$ isolates from healthy animals and was present in a single Staph. aure$u s$ strain and 7 out of $62(11.3 \%)$ CNS strains. In cows with mastitis, the prevalence of this gene was higher $(16.3 \%)$; it was detected in $3(21.4 \%)$ Staph. aureus strains and in $10(15.2 \%)$ CNS strains.

The selk gene was not observed in any strain. The seq gene was also negative in all isolates and both of these genes can be found together in the pathogenicity island SaPI1, which also contains the seb gene. The seb gene also occurred at a low rate $(3.2$ and $1.5 \%$ of CNS strains isolated from the milk of healthy cows and cows with mastitis, respectively), and the difference in the prevalence of this gene was not significant between the 2 groups $(P=0.58)$. Relatively few papers have described the detection of these genes. Wang et al. (2009) detected seb in $2.1 \%$ and selk in $3.2 \%$ of 283 Staph. aureus strains isolated from subclinical mastitis, whereas $s e q$ was not examined in this study. Omoe et al. (2005) found higher frequencies of these genes and observed frequencies of $30.1,22.9$, and $21.1 \%$ positivity for the seb, selk, and selq genes, respectively, although that study examined human clinical isolates and not those from livestock.

In our study, strains of Staphylococcus that possessed genes for the production of classical enterotoxins were tested for the production of these enterotoxins. We observed that 8 of $15(53.3 \%)$ Staph. aureus strains from healthy cows and cows with mastitis contained the sea gene and all of these strains produced the toxin. In the CNS strains, only 1 strain (Staph. epidermidis) out of $128(0.8 \%)$ containing the gene produced the SEA toxin. None of the CNS strains that contained the seb or sed genes produced these toxins. In our examination of sec, 2 Staph. aureus strains containing sec produced the SEC enterotoxin and 6 CNS strains did not. This lack of enterotoxin production by CNS strains despite the presence of the toxin genes has been reported previously (Rall et al., 2010; Aydin et al., 2011). 
With the exception of Staph. aureus strains, which occurred predominantly in cows with mastitis, the other species of CNS were found indiscriminately in both groups of animals. Moreover, despite the presence of genes encoding classical enterotoxins in many CNS strains, only one strain produced these toxins. Further research is needed to demonstrate the true pathogenic potential of this group of organisms in mastitis.

\section{ACKNOWLEDGMENTS}

The authors thank Fundação de Amparo à Pesquisa do Estado de São Paulo (FAPESP, São Paulo, Brazil) for financial support.

\section{REFERENCES}

Akineden, O., C. Annemuller, A. Hassan, C. Lammler, W. Wolter, and M. Zschock. 2001. Toxin genes and other characteristics of Staphylococcus aureus isolates from milk of cows with mastitis. Clin. Diagn. Lab. Immunol. 8:959-964.

Atanassova, V., A. Meindl, and C. Ring. 2001. Prevalence of Staphylocccus aureus and staphylocccocal enterotoxins in raw pork and uncooked smoked ham-A comparison of classical culturing detection and RFLP-PCR. Int. J. Food Microbiol. 68:105-113.

Aydin, A., M. Sudagidan, and K. Muratoglu. 2011. Prevalence of staphylococcal enterotoxins, toxin genes and genetic-relatedness of foodborne Staphylococcus aureus strains isolated in the Marmara Region of Turkey. Int. J. Food Microbiol. 148:99-106.

Baba, T., F. Takeuchi, M. Kuroda, H. Yazawa, K. Aoki, Y. Oguchi, Y. Nagai, N. Iwama, K. Asano, T. Naimi, H. Kuroda, L. Cui, K. Yamamoto, and K. Hiramatsu. 2002. Genome and virulence determinants of high virulence community-acquired MRSA. Lancet 359:1819-1827.

Bergdoll, M. S., and R. N. Robbins. 1973. Characterization of types of staphylococcal enterotoxins. J. Milk Food Technol. 36:610-612.

Betley, M. J., D. W. Borst, and L. B. Regassa. 1992. Staphylococcal enterotoxins, toxic shock syndrome toxin and streptococcal pyrogenic exotoxins: A comparative study of their molecular biology. Chem. Immunol. 55:1-35.

Boynukara, B., T. Gulhan, M. Alisarli, K. Gurturk, and H. Solmaz. 2008. Classical enterotoxigenic characteristics of Staphylocccus aureus strains isolated from bovine subclinical mastitis in Van, Turkey. Int. J. Food Microbiol. 125:209-211.

Chiang, Y. C., L. T. Chang, C. W. Lin, C. Y. Yang, and H. Y. Tsen, 2006. PCR primers for the detection of staphylococcal enterotoxins $\mathrm{K}, \mathrm{L}$, and $\mathrm{M}$ and survey of staphylococcal enterotoxin types in Staphylococcus aureus isolates from food poisoning cases in Taiwan. J. Food Prot. 69:1072-1079.

Cremonesi, P., M. Luzzana, M. Brasca, S. Morandi, R. Lodi, C. Vimercati, D. Agnellini, G. Caramenti, P. Moroni, and B. Castiglioni. 2005. Development of a multiplex PCR assay for the identification of Staphylococcus aureus enterotoxigenic strains isolated from milk and dairy products. Mol. Cell. Probes 19:299-305.

Donnelly, C. B., J. E. Leslie, L. A. Black, and K. H. Lewis. 1967. Serological identification of enterotoxigenic staphylococci from cheese. Appl. Microbiol. 15:1382-1387.

DSMZ (Deutsche Sammlung von Mikroorganismen und Zellkulturen GmbH). 2012. Prokaryotic nomenclature up-to-date. Accessed Mar. 27, 2012. http://old.dsmz.de/microorganisms/bacterial_ nomenclature_info.php?genus=Staphylococcus\&show_all_details $=1$.

Fessler, A. T., C. Billerbeck, K. Kadlec, and S. Schwarz. 2010. Identification and characterization of methicillin-resistant coagulasenegative staphylococci from bovine mastitis. J. Antimicrob. Chemother. 65:1576-1582.
Gillespie, B. E., S. I. Headrick, S. Boonyayatra, and S. P. Oliver. 2009 Prevalence and persistence of coagulase-negative Staphylococcus species in three dairy research herds. Vet. Microbiol. 134:65-72.

Holtfreter, S., and B. M. Broker. 2005. Staphylococccal superantigens: Do they play a role in sepsis? Arch. Immunol. Ther. Exp. 53:13-27.

Hwang, S. Y., S. H. Kim, E. J. Jang, N. H. Kwon, Y. K. Park, H. C. Koo, W. K. Jung, J. M. Kim, and Y. H. Park. 2007. Novel multiplex PCR for the detection of the Staphylococcus aureus superantigen and its application to raw meat isolates in Korea. Int. J. Food Microbiol. 117:99-105.

Jarraud, S., M. A. Peyrat, A. Lim, A. Tristan, M. Bes, C. Mougel, J. Etienne, F. Vandenesch, M. Bonneville, and G. Lina. 2001. Egc, a highly prevalent operon of enterotoxin gene, forms a putative nursery of superantigens in Staphylococcus aureus. J. Immunol. 166:669-677.

Johnson, W. M., S. D. Tyler, P. Ewan, F. E. Ashton, D. R. Pollard, and K. R. Rozee. 1991. Detection of genes for enterotoxins, exfoliative toxins, and toxic shock syndrome toxin 1 in Staphylococcus aureus by the polymerase chain reaction. J. Clin. Microbiol. 29:426-430.

Karahan, M., M. N. Açik, and B. Cetinkaya. 2009. Investigation of toxin genes by polymerase chain reaction in Staphylocccus aureus strains isolated from bovine mastitis in Turkey. Foodborne Pathog. Dis. 6:1029-1035.

Kuroda, M., T. Ohta, I. Uchiyama, T. Baba, H. Yuzawa, I. Kobayashi, L. Cui, A. Oguchi, K. Aoki, Y. Nagai, J. Lian, Y. Ito, M. Kanamori, H. Matsumaru, A. Maruyama, H. Murakami, A. Hosoyama, Y. Mizutani-Ui, N. K. Takahashi, T. Sawano, R. Inoue, C. Kaito, K. Sekimizu, H. Hirakawa, S. Kuhara, S. Goto, J. Yabuzaki, M. Kanehisa, A. Yamashita, K. Oshima, K. Furuya, C. Yoshino, T. Shiba, M. Hattori, N. Ogasawara, H. Hayashi, and K. Hiramatsu. 2001. Whole genome sequencing of methicillin-resistant Staphylococcus aureus. Lancet 357:1225-1240.

Letertre, C., S. Perelle, F. Dilasser, and P. Fach. 2003. Identification of a new putative enterotoxin SEU encoded by the egc cluster of Staphylococcus aureus. J. Appl. Microbiol. 95:38-43.

Lina, G., G. A. Bohach, S. P. Nair, K. Hiramatsu, E. Jouvin-Marche, and R. Mariuzza. 2004. Standard nomenclature for the superantigens expressed by Staphylococcus. J. Infect. Dis. 189:2334-2336.

Lüthje, P., and S. Schwarz. 2006. Antimicrobial resistance of coagulase-negative staphylococci from bovine subclinical mastitis with particular reference to macrolide-lincosamide resistance phenotype and genotypes. J. Antimicrob. Chemother. 57:966-969.

Mason, W. J., J. S. Blevins, K. Beenken, N. Wibowo, N. Ojha, and M. S. Smeltzer. 2001. Multiplex PCR protocol for the diagnosis of staphylococcal infection. J. Clin. Microbiol. 39:3332-3338.

Mehrotra, M., G. Wang, and W. M. Johnson. 2000. Multiplex PCR for detection of genes for Staphylococcus aureus enterotoxins, exfoliative toxins, toxic shock syndrome toxin 1 , and methicillin resistance. J. Clin. Microbiol. 38:1032-1035.

Melchior, M. B., J. Fink-Gremmels, and W. Gaastra. 2006. Comparative assessment of the antimicrobial susceptibility of Staphylococcus aureus isolates from bovine mastitis in biofilm versus planktonic culture. J. Vet. Med. B Infect. Dis. Vet. Public Health 53:326-332.

Mempel, M., G. Lina, M. Hojka, C. Schnopp, H.-P. Seidl, T. Schäfer, J. Ring, F. Vandenesch, and D. Abeck. 2003. High prevalence of superantigens associated with the egc locus in Staphylococcus aureus isolates from patients with atopic eczema. Eur. J. Clin. Microbiol. Infect. Dis. 22:306-309.

Morandi, S., M. Brasca, R. Lodi, P. Cremonesi, and B. Castiglione. 2007. Detection of classical enterotoxins and identification of enterotoxin genes in Staphylocccus aureus from milk and dairy products. Vet. Microbiol. 124:66-72.

Munson, S. H., M. T. Tremaine, M. J. Betley, and R. A. Welch. 1998. Identification and characterization of staphylococcal enterotoxin types G and I from Staphylococcus aureus. Infect. Immun. 66:3337-3348.

Nashev, D., K. Toshkova, S. I. O. Salasia, A. A. Hassan, C. Lämmler, and M. Zschöck. 2004. Distribution of virulence genes of Staphylo- 
coccus aureus isolated from stable nasal carriers. FEMS Microbiol. Lett. 233:45-52.

Omoe, K., D. L. Hu, H. Takahashi-Omoe, A. Nakane, and K. Shinagawa. 2005. Comprehensive analysis of classical and newly described staphylococcal superantigenic toxin genes in Staphylococcus aureus isolates. FEMS Microbiol. Lett. 246:191-198.

Omoe, K., D. L. Hu, H. Takahashi-Omoe, A. Nakane, and K. Shinagawa. 2003. Identification and characterization of a new staphylococcal enterotoxin-related putative toxin encoded by two kinds of plasmids. Infect. Immun. 71:6088-6094.

Omoe, K., M. Ishikama, Y. Shimoda, D. L. Hu, S. Ueda, and K. Shinagawa. 2002. Detection of seg, seh and sei genes in Staphylococcus aureus isolates and determination of the enterotoxin productivities of S. aureus isolate harboring seg, seh or sei genes. J. Clin. Microbiol. 40:857-862.

Ono, H. K., K. Omoe, K. Imanishi, Y. Iwakabe, D. L. Hu, H. Kato, N. Saito, A. Nakane, T. Uchiyama, and K. Shinagawa. 2008. Identification and characterization of two novel staphylococcal enterotoxins, types S and T. Infect. Immun. 76:4999-5005.

Orwin, P. M., J. R. Fitzgerald, D. Y. M. Leung, J. A. Gutierrez, A. G. Bohach, and P. M. Schlievert. 2003. Characterization of Staphylococcus aureus enterotoxin L. Infect. Immun. 71:2916-2919.

Orwin, P. M., D. Y. M. Leung, H. L. Donahue, R. P. Novick, and P. M. Schlievert. 2001. Biochemical and biological properties of staphylococcal enterotoxin K. Infect. Immun. 69:360-366.

Pantoja, J. C. F., C. Hulland, and P. L. Ruegg. 2009. Somatic cell count status across the dry period as a risk factor for the development of clinical mastitis in the subsequent lactation. J. Dairy Sci. 92:139-148.

Park, J. Y., L. K. Fox, S. K. Seo, M. A. McGuire, Y. H. Park, F. R. Rurangirwa, W. M. Sischo, and G. A. Bohach. 2011. Comparison of phenotypic and genotypic methods for the species identification of coagulase-negative staphylococcal isolates from bovine intramammary infections. Vet. Microbiol. 147:142-148.

Philpot, W. N., and S. C. Nickerson. 2002. Vencendo a luta contra a mastite. Editora Milkbizz Ltda, São Paulo, Brazil.

Pol, M., and P. L. Ruegg. 2007. Relationship between antimicrobial drug usage and antimicrobial susceptibility of gram-positive mastitis pathogens. J. Dairy Sci. 90:262-273.

Poyart, C., G. Quesne, C. Boumaila, and P. Trieu-Cuot. 2001. Rapid and accurate species-level identification of coagulase-negative staphylococci by using the $\operatorname{sod} A$ gene as a target. Clin. Microbiol. 39:4296-4301.

Pyörälä, S., and S. Taponen. 2009. Coagulase-negative staphylococciEmerging mastitis pathogens. Vet. Microbiol. 134:3-8.

Rajala-Schultz, P. J., K. L. Smith, J. S. Hogan, and B. C. Love. 2004. Antimicrobial susceptibility of mastitis pathogens from first lactation and older cows. Vet. Microbiol. 102:33-42.

Rall, V. L. M., J. M. Sforcin, M. F. Deus, D. C. Sousa, C. H. Camargo, N. C. Godinho, L. A. Galindo, T. C. S. Soares, and J. P. Araújo Júnior. 2010. PCR detection of enterotoxins genes in coagulase negative staphylococci isolated from Brazilian Minas cheese. Foodborne Pathog. Dis. 7:1121-1123.
Ren, K., J. D. Bannan, V. Pancholi, A. L. Cheung, J. C. Robbins, V. A. Fischetti, and J. B. Zabriskie. 1994. Characterization and biological properties of a new staphylococcal exotoxin. J. Exp. Med. 180:1675-1683.

Robbins, R., S. Gould, and M. Bergdoll. 1974. Detecting the enterotoxigenicity of Staphylococcus aureus strains. Appl. Microbiol. 28:946-950.

Ruaro, A., C. Andrighetto, S. Torriani, and A. Lombardi. 2013. Biodiversity and characterization of indigenous coagulase-negative staphylococci isolated from raw milk and cheese of North Italy. Food Microbiol. 34:106-111.

Santos, L.L, T.F. Fogaça, and E. Pedroso. 2010. Perfil etiológico da mastite bovina na bacia leiteira de Santa Izabel do oeste, Paraná. Ciência Animal Brasileira 11:860-866.

Sawant, A. A., B. E. Gillespie, and S. Oliver. 2009. Antimicrobial susceptibility of coagulase-negative Staphylococcus species isolated from bovine milk. Vet. Microbiol. 134:73-81.

Schalm, O. W., and D. O. Noorlander. 1957. Experiments and observations leading to development of the California mastitis test. J. Am. Vet. Med. Assoc. 130:199-204.

Supré, K., F. Haesebrouck, R. N. Zadoks, M. Vaneechoutte, S. Piepers, and S. De Vliegher. 2011. Some coagulase-negative Staphylococcus species affect udder health more than others. J. Dairy Sci. 94:2329-2340

Taponen, S., J. Bjorkroth, and S. Pyörälä. 2008. Coagulase-negative staphylococci isolated from bovine extramammary sites and intramammary infections in a single dairy herd. J. Dairy Res. 75:422429

Taponen, S., J. Koort, J. Bjorkroth, H. Saloniemi, and S. Pyörälä. 2007. Bovine intramammary infections caused by coagulase-negative staphylococci may persist throughout lactation according to amplified fragment length polymorphism-based analysis. J. Dairy Sci. 90:3301-3307.

Taponen, S., H. Simojoki, M. Haveri, H. D. Larsen, and S. Pyörälä. 2006. Clinical characteristics and persistence of bovine mastitis caused by different species of coagulase-negative staphylococci identified with API or AFLP. Vet. Microbiol. 115:199-207.

Thomas, D. Y., S. Jarraud, B. Lemercier, G. Cozon, K. Echasserieau, J. Etienne, M.-L. Gougeon, G. Lina, and F. Vandenesch. 2006. Staphylococcal enterotoxin-like toxins U2 and V, two new staphylococcal superantigens arising from recombination within the enterotoxin gene cluster. Infect. Immun. 74:4724-4734.

Wang, S. C., C. M. Wu, S. C. Xia, Y. H. Qi, L. N. Xia, and J. Z. Shen, 2009. Distribution of superantigenic toxin genes in Staphylocccus aureus isolates from milk samples of bovine subclinical mastitis cases in two major dairy production regions of China. Vet. Microbiol. 137:276-281.

Weese, J. S. 2012. Staphylococcal control in the veterinary hospital. Vet. Dermatol. 23:292-298.

Zhang, S., J. J. Iandolo, and G. C. Stewart. 1998. The enterotoxin D plasmid of Staphylococcus aureus encodes a second enterotoxin determinant (sej). FEMS Microbiol. Lett. 168:227-233. 